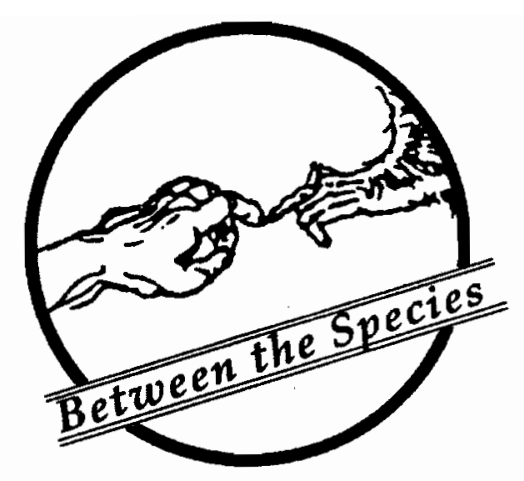

\title{
ANIMAL LIBERATION AND THE GREAT AWAKENING
}

\author{
Clay Lancaster \\ Salvisa, Kentucky
}

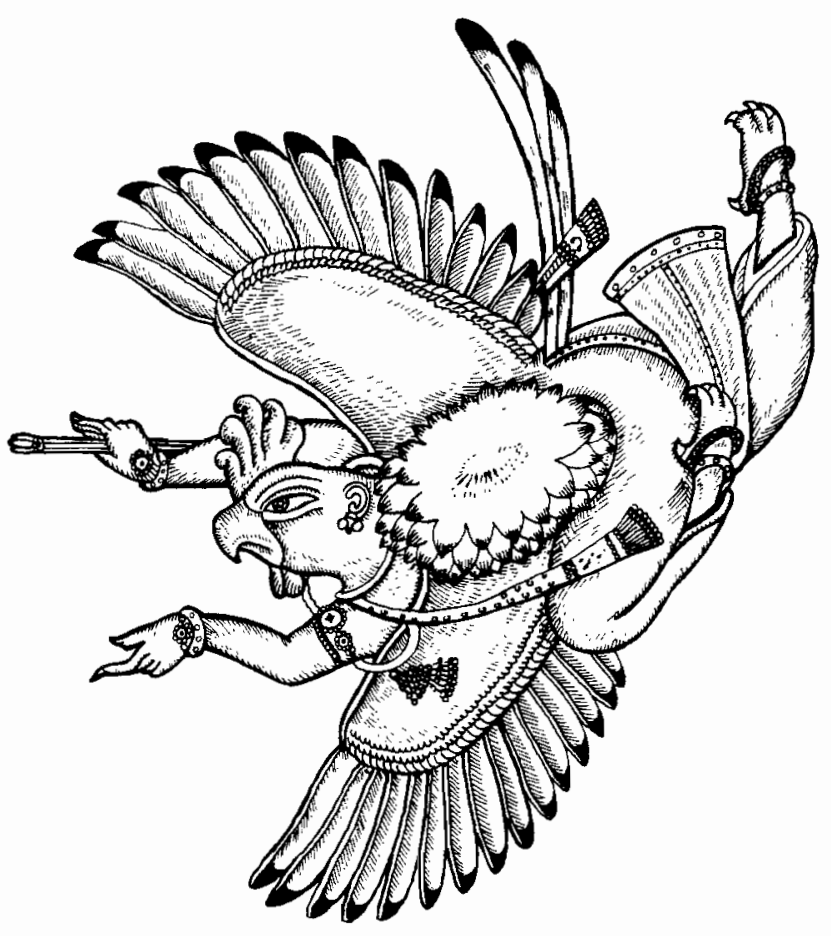

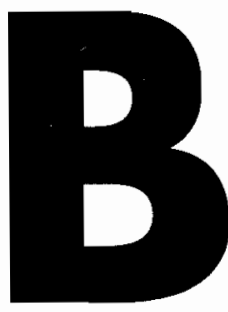

rought up in a world whose culture and religion are rooted in the civilizations of the eastern crescent of the Mediterranean Sea, one is led to believe that the progress made in overcoming the prejudice that Peter Singer calls speciesism is of relatively recent development. But this stems from the limitations of the Western background; animal liberation has been known and widely practiced in Farther Asia for millennia.

The original of the sculpture on p.66 is in the Indian Museum, Calcutta. Used with permission of Dr. R. C. Sharma, Director.

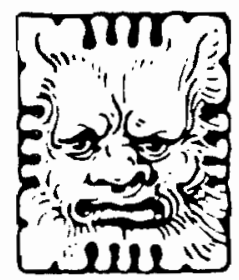


The Greeks adhered to the narrow principle that man is the measure of all things. The human figure was the chief subject of their painting, sculpture, and literature. Horses, pets, and hunted and sacrificial animals only occasionally appeared in Hellenic art as an adjunct to the human theme, and animals sometimes were used as decorative motifs, the latter usually of a fantastic, composite nature. The gods were strictly anthropomorphic. They even consorted with humans, and begot demi-gods, like Herakles with his superhuman strength, and Helen of Troy with her superlative beauty. On the other hand, mythological beings that were half man and half beast were considered evil monsters, like the Minotaur, who devoured Athenian youths and maidens, a wickedness that did not stem from the bull side of his makeup.

The situation was somewhat amended on the south side of the Mediterranean Sea. Many Egyptian deities were partly or wholly animal, and most were beneficent. The sun god $\mathrm{Ra}$, or Horus, had either the head or the entire form of a falcon; the Egyptian Aphrodite, Hathor, had either the head or the form of a cow; Anubis, guide to the underworld, was jackal-headed; and Taueret, patron of maternity, was a hippopotamus. In such an atmosphere, liberated from strict anthropomorphism, during the fourteenth Century B.C. the pharaoh Amenhotep IV abandoned the pantheon and instituted the worship of the abstract sun disk Aten, changing his own name to Akhenaten, "servant of Aten." It was the first-known monotheism, and a nearbreak with theism. Moses' concept of henotheism, conceived in Egypt (or Midian) a century later, undoubtedly stemmed from the heresy of Akhenaten. Significantly, in the Hymns of Akhenaten, domestic animals and wildlife join man in praising the creator. The eminent Egyptologist James Henry Breasted has pointed out in his book The Daun of Conscience that a characteristic Akhenaten hymn appears in the Bible as Psalm 104. Isaiah pictured the Peaceable Kingdom as one in which "the wolf ... shall dwell with the lamb, and the leopard shall lie down with the kid; and the calf and the young lion and the fatling together"; but it is a unique acknowledgement in the Old Testament. Animals are given no better status in the New Testament. The apostle Paul said that the flesh of men, beasts (mammals), fishes and birds were not the same, which is scientifically more inaccurate than not, and contributed to the Christian resistance to evolution. St. Augustine's scorn of animals became so ingrained that even after the power of the church was modified by secular forces during the Renaissance, the animals remained subject to man's greed and tyranny in the West.

Yet there have been isolated groups which had a broader viewpoint and a more merciful regard for beasts in Europe. Pythagoras founded such a school at Crotona in southern Italy during the sixth century B.C. Numbers, musical harmony, equality of the sexes, and humaneness were important factors in the Pythagorean system. Mythical deities were eschewed. In the late fifth century the Crotona colony was attacked by rigid conformists, and the Pythagoreans were either killed or fled. Some of their ideas turned up in the discourses of Socrates and Plato. Francis of Assisi was Christianity's most revered medieval saint, and he had genuine concern for the "little brothers." A number of contemporary dissenter groups were as idealistic and non-speciesistic, such as the Albigenses and Waldenses of southern France. They were followed by others during the Reformation; but, unfortunately, when the final break with the Roman church occurred, Protestant congregations perpetuated the traditionally Christian unsympathetic attitude toward animals.

Hinduism was never as anthropomorphic as Western mythologies. Surya was both the sun and sun god, Chandra the moon and moon god, Agni the fire and fire god, and Vayu the wind and the air deity. The phenomena and their spiritual essences were so closely connected that in reading the Vedas one is often at a loss to determine which or what is being addressed. Only after several centuries into our era were the Hindu gods depicted in art. However, they never assumed the anatomical fidelity of Greek deities, but maintained special features that distinguished them from humans. Animals figure prominently in Indian legends and iconography. As in Egypt, a few of the Hindu gods were zoocephalic, like the elephant-headed Ganesha, pro- 
moter of wisdom and remover of obstacles; and all of the gods had an animal vahana, or mount, like Ganesha's rat, Siva's bull, Brahma's swan, and Vishnu's golden bird. In a number of Hindu myths the gods assume animal forms to fulfill a specific purpose. Vishnu became a wild boar to plunge into the ocean and retrieve the elixir of immortality, and a lion to rescue a pious follower from abuse. Vishnu also incarnated as the youth Krishna to evict the troublesome serpent king Kaliya from a stream, so that villagers and their cattle might drink unmolested.

\section{Whereas killing is a sin only of other tribesmen according to the Mosaic} Ten Commandments, or of other members of the sect in Christianity..., in the Indian systems it encompasses all conscious forms of life.

It is not surprising that such a national attitude should develop into man's first awareness of animals' rights. It was parcel of the intellectual ferment that took place in India during the sixth century B.C., referred to as the Great Awakening. The watchword was Satya, "Truth." Thousands participated, and their methods varied greatly. Some resorted to the frivolity of hedonism, and others the austerity of mortification; some submitted completely to teachers, others sought liberation and self-mastery; and some became theists, some atheists, and others agnostics. There were conobites gathered in communities, and anchorites and ascetics scattered throughout the wilderness. After trying one system they might change to another, and then another, until they found the one that suited them best. It was a free and wholesome movement that not surprisingly made enduring worthwhile contributions to civilization.

Conspicuous are the systems that originated during the Great Awakening. Hinduism itself changed into a philosophy religion. The name of the creator god in the Vedas, Brahma (masculine), in the Upanishads was altered to Brahma or Brahman (neuter), which signified God as the Cosmic Force or Soul of the Universe, not as an entity apart but inherent in the universe. This monism went beyond the hitherto most advanced thinking of Akhenaten's monotheism It is conceivable that this one momentous idea traveled rapidly throughout the civilized world turning up soon afterward as the Tao in China, and as the Logos among the Greek philosophers. In its native India it provided the key to three important disciplines.

The first is Yoga, which word means "union," and which seeks unity within the self and unification of the self with the world in which it resides. The principal form is Hatha ("force"), and through training and practice the yogin gains control of his body and mind. After more than twenty-five centuries, Hatha Yoga exercises remain the best physical fitness regimen that has ever been devised. The higher steps are referred to as Raja ("royal") Yoga. They transcend the physical and deal with techniques of dhyana ("meditation") to achieve samadhi ("coming together"), the ultimate universal attainment. There are also Karmic ("works") Yoga, of performing charitable deeds, and Bhakti ("devotion") Yoga, of self-effacing resignation; but these are conciliatory addenda for those temperamentally unsuited for discipline.

The second system is Jainism, founded by Vardhamana, titled Mahavira ("great hero"), which is atheistic. In place of deities the Jains venerate the Jinas ("conquerors") - whence the name Jainism derives - and Tirthankaras ("guides"). The world view of Jainism is compli- 


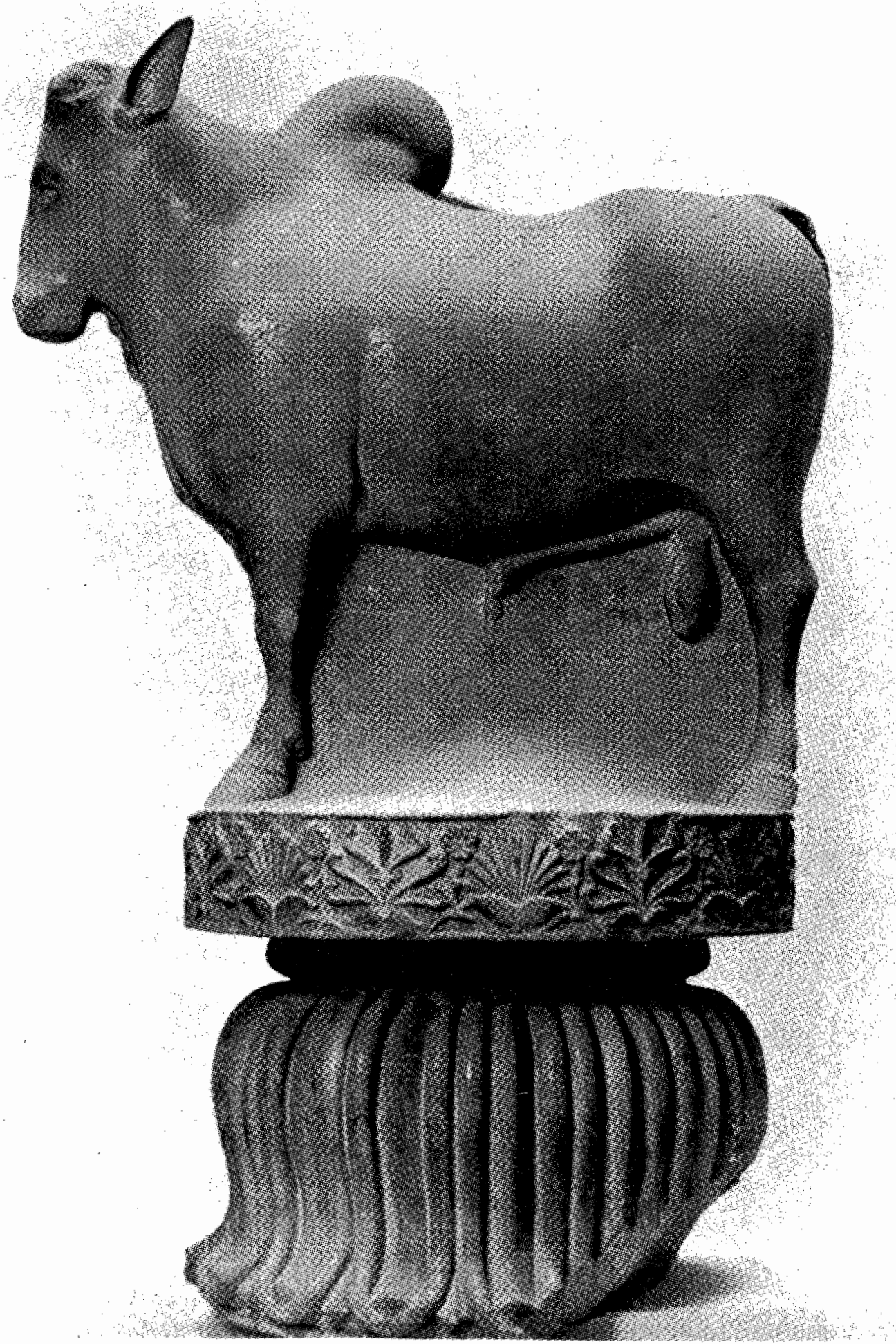

Bun Capra of an Asokn Prar. Polishel sandsone, from Rampurä, Bhar. Mauryn, 3 d century n. 
cated. It focuses upon jiva ("souls"), as opposed to ajiva ("no-souls"), and the extent of their existence, in the air, in water, and on and in the earth. It anticipated the existence of bacteria at least two millennia before the invention of the microscope. Living beings are divided into six categories according to their sensations. The lowest are those with only the sense of touch, above which are those having also the sense of taste, then those with three senses, including smell; next are those with also the sense of sight; the fifth includes hearing; and the highest, having all six, incorporates thinking. It was the most perceptive interpretation of biology of its day, and it was integral with the Jain ethical system governed by ahimsa ("harmlessness"), which was the original declaration of reverence for life. Jainism, like Yoga, remained a sect of Hinduism, and both exerted an influence upon the parent institution.

The paramount system to emerge from the Great Awakening is Buddhism. It originated in the teaching of Siddhartha, a prince who renounced his inheritance to a kingdom on the border of Nepal to seek enlightenment. Like the other seekers of his time, he applied to many sages and followed their methods, only to find them limited. Living itself, he concluded, is limited, and the best one can do is seek Truth unencumbered by preconceived dogmas or blind faith. One should observe and analyze, and (as recorded in the Kalama Sutta) "when it agrees with reason and is conducive to the good and gain of one and all, then accept it and live up to it." There is an intellectual fluidity in accepting something not to be found in believing it; and there is ethical universality in considering the consequences upon others. The logic of Siddhartha is clearer and more encompassing than that of Aristotle, who got bogged down by the mechanics of the syllogism two hundred years later. In Buddhism the universe is to be accepted as it stands, evolved rather than created. Gods - if they exist - are subject to the same law as man and all other members and components of the physical world; and that law, called dharma, is cause and effect. All animate beings result from the will to particularize, to function as an ego, and with it trouble begins.
One is then lost in samsara, the world of change and illusions. Escape is through circumventing attachments and seeking prajna ("wisdom"), transcending mentation for insight into nirvana (the "blown out" state). Nirvana has been called extinction. It is, but only in the sense of extinguishing the petty self for a larger one, extinguishing distinctions, and attaining universality. It is Enlightenment, Buddhahood; and he who has reached it is a Buddha, as was Siddhartha. There is a concomitant to wisdom in Enlightenment, and this is karuna ("love" or compassion), which is the consciousness of kinship with all sentient beings who are caught in the maelstrom of samsara. Wisdom and love are complementary, neither being complete without the other.

Yoga, Jainism and Buddhism embrace similar ethics. The five rules of conduct in Buddhism are (1) not to kill, (2) not to steal, (3) not to lie, (4) not to commit adultery, and (5) not to indulge in intoxicants. Yoga prescribes the first four, and substitutes non-hoarding for the fifth. Jainism follows similar restrictions, though it specifically forbids gambling, and makes no particular issue of the second and third Buddhist precepts. Whereas killing is a sin only of other tribesmen according to the Mosaic Ten Commandments, or of other members of the sect in Christianity (at least up through the seventeenth century), in the Indian systems it encompasses all conscious forms of life. Near Eastern immortality is restricted to some men, and it entails resurrected bodies. In India all men and creatures have a disengaging soul, and immortality is common to them all. The Hindus subscribe to reincarnation, or rebirth in a form similar to that which one had before. Buddhism, more cautiously, accepts metempsychosis - some sort of soul migration - without pinning it down. It points out that the individual ego is no more permanent than any other particular. Immortality merely means surviving death, changing into something else with an uncertain element of identity. It is a logical impossibility that a finite being can exist as such throughout an infinity of time. The finite must transcend to the universal to become eternal.

The Great Awakening contributed substantially to practical matters, especially in the field of medicine. The Carakasamhita contains three 
times as much material as was in the Hippocratic writings. The Susrutasamhita lists eleven hundred diseases that were treated, using seven hundred and sixty plants (besides animal products and drugs), and twenty sharp and a hundred blunt instruments that were employed in surgery. Concern for life was an important factor in ancient Indian medical practice. Dissecting human corpses was frowned upon, being engaged in only by experienced physicians. The same was true for Europe, only among the Greeks and Romans there was no hesitancy in substituting vivisection of animals, and little heed for the suffering caused. In India, on the other hand, alternatives for animals in research and teaching (The American Fund for Alternatives to Animal Research was founded in New York City in 1977) were already used more than two millennia ago. Surgical students practiced making incisions on gourds, and excisions on water bags; probing was exercised on worm-eaten wood and bamboo, and extracting teeth by drawing seeds from jack-fruit. A life-size linen doll served as model for applying bandages and dressings. Far from proving a hindrance, by these means the Indians became the world's leaders in surgical skills. The Greeks did not approach them in efficiency until Alexandria became the capital of the Hellenistic world, and communication and trade with India crossed the Arabian Sea. Already in the sixth century B.C. the Indians recorded their performing eye and brain operations, the removal of gall stones, and plastic surgery. Alcohol was used as a soporific. Immunization from smallpox by vaccination was known to them at least two thousand years before it reached Europe, and their treatment of leprosy and control of hypertension are basically unchanged.

Progress made in medicine in ancient India not only refrained from harming and maiming animals but benefitted them, as veterinarian science developed simultaneously. A sixthcentury B.C. treatise called Gavayurveda ("bovine-medicine-knowledge") dealt with the diseases and treatment of cattle. The Samhita of Salihotra similarly concerned horses. The Hastyayurveda, attributed to the sage Palakapya, concentrated on elephants. These books in their entirety are lost, but fragments from them and notices about them are to be found in subsequent works. The Greek ambassador to the court of Chandragupta in the late fourth century B.C. wrote a thesis on elephant ailments, presumably based on the Hastyayurveda.

Chandragupta expelled the last of the garrisons established by Alexander the Great from India, and founded the native Mauryan dynasty. His grandson Asoka extended the empire until it was larger than that which was to become the British Raj. He felt such remorse over the suffering caused by his last campaign into Kalinga that he embraced Buddhism, and gave up war altogether. Asoka abolished slavery and the caste system, and he instituted ahimsa as the creed of the nation, declaring that no longer would an animal be killed to provision the royal table, and he admonished his subjects to follow his example. Asoka caused edicts to be inscribed on great monolithic columns, each capped by a magnificent animal sculpture, erected throughout the realm. They forbade people to "kill any living animal," as the ruler "ardently desires security for all creatures, respect for life, peace and kindliness in behavior." The Asokan edicts were virtually the first civil rights that were bestowed upon animals. Some of the pillars are still standing. Asoka consummated the proclamations by providing sanctuaries, digging wells, importing and raising medicinal plants, and building hospitals for the benefit of animals as well as people. Asoka also sponsored a convocation of all religions at his capital, Pataliputra, and those of acceptable moral code were propagated at state expense. It should be stressed that, following the Great Awakening, religion meant peaceful cohabitation and benevolence. Throughout Farther Asia it would have been unthinkable that such bloody atrocities as the Crusades, the Inquisition, and the ProtestantCatholic wars could be prompted by religion, as in the West.

Under the emperor Asoka many millions of people in India were given an acute awareness of tolerance and sympathy for the non-human citizens of this planet. Asoka sent missionaries to propagate the virtues in neighboring lands, his own son and daughter introducing Buddhism 
into Sri Lanka. Wherever Buddhism went, civilization surged upward, learning increased, the arts flourished, and people became gentler and more compassionate. India's counterpart in ancient culture in Asia, China, adopted Buddhism, and under its tutelage were produced some of the world's most beautiful objects of art. The oldest printed book is the Buddhist Diamond Sutra, in Chinese, dated according to our reckoning as 11 May 868, which was almost six hundred years before Gutenberg printed the first Bible. Through Buddhism, the fierce barbarians in the rugged uplands of Tibet became one of the most temperate of nations. Judging by its remains, the most magnificent capital created by man was that of Angkor in Cambodia. Its definitive form was achieved under the eleventh-century king Jayavarman VII, like Asoka a Buddhist convert, who promoted equivalent institutions beneficial to man and beast. Korea and Japan and other Far Eastern countries enjoyed long eras of peace and gracious living when motivated by the same adherence to intrinsic values.

One justifiably may ask what has become of the amenities of the Great Awakening. Some still exist. The population of southern Asia, after more than two-dozen centuries, remains largely vegetarian. But much, if not most, of this civilization has changed drastically, to a great extent due to centuries of Western imperialism and exploitation. The illicit traffic in liquor, opium and drugs in Asia, by which English, European and American traders enriched themselves, now has become more of a problem at home than there. The West tempted the East in to the worship of the Almighty Dollar by offering the luxuries, conveyances, gadgetry, and mechanical diversions and amusements that can be purchased by it. The East abandoned its indigenous tranquillity for the confused aggressiveness of the West. Enlightenment has become obscured by the litter and pollution that emanate from the materialism that descended from the anthropocentric restrictions of Classical antiquity, and egocentric suppressions of the Dark Ages; but it is inextinguishable, and it continues to illuminate, somewhat, a bewildered and brutal world.

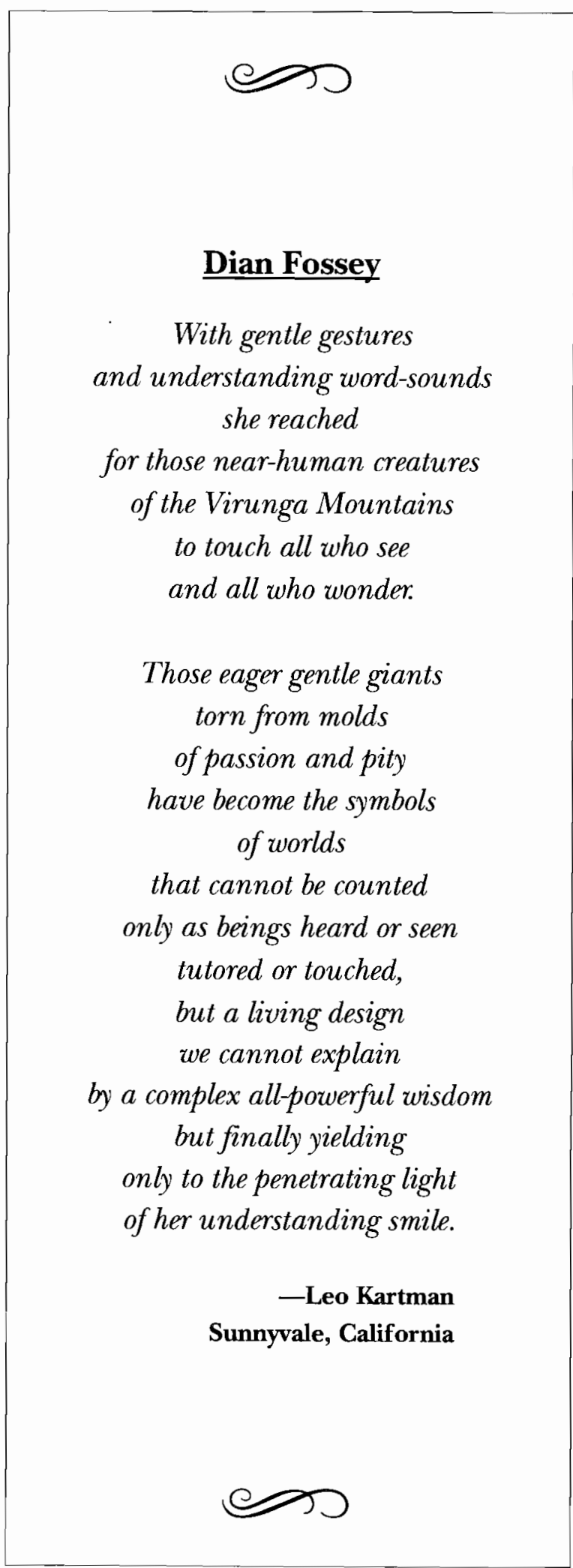

